\title{
icaA/D GENES AND BIOFILM FORMATION OF METHICILLIN-RESISTANT Staphylococcus aureus IN DR. SOETOMO HOSPITAL, SURABAYA
}

\author{
Putu Arya Suryanditha ${ }^{1}$, Yoeke Dewi Rasita ${ }^{2}$, Kartuti Debora ${ }^{3}$, K. Kuntaman ${ }^{1,3,4}$ \\ ${ }^{1}$ Master Program of Basic Medical Science, Faculty of Medicine, Universitas Airlangga, Surabaya, ${ }^{2}$ Central Health \\ Laboratory, Makassar, ${ }^{3}$ Department of Microbiology, Faculty of Medicine, Universitas Airlangga/Dr Soetomo Hospital, \\ Surabaya, ${ }^{4}$ Institute of Tropical Disease, Universitas Airlangga, Surabaya, Indonesia
}

\section{ABSTRACT}

\begin{abstract}
Methicillin-resistant Staphylococcus aureus (MRSA) is a global health concern. One of the factors causing hospital infection is related to the ability of MRSA bacteria to form biofilms. Polysaccharide intercellular adhesin (PIA), encoded by ica gene, have an important role in $S$. aureus intracellular accumulation and aggregation. The aims of this study was to analyze the relationship between icaA, icaD genes and biofilm production in MRSA carrier and clinical isolate in Dr. Soetomo Hospital Surabaya. This study was an observational study using cross sectional approach. The sample was 47 MRSA isolates is as follow 28 isolates from carrier and 19 were clinical isolates. All of MRSA isolates carried mecA gene. PCR was performed to detect icaA and icaD genes. Biofilm formation was detected using microtiter plate assay (MTP). icaA gene was detected in all isolates whereas icaD gene in 96,4\% carrier isolates and all (100\%) of clinical isolates. Positive MTP results showed in all (100\%) of carrier isolates and 57,9\% of clinical isolates. Statistic result was significantly different in biofilm formation between carrier and clinical MRSA isolates. The proportion of positive biofilm formation in isolate with positive icaA/D genes was $82.6 \%$. There was not any association between icaA and icaD gene with biofilm production.
\end{abstract}

Keywords: Biofilm; ica gene; methicillin-resistant Staphylococcus aureus

\section{ABSTRAK}

Methicillin-resistant Staphylococcus aureus (MRSA) menjadi masalah kesehatan di seluruh dunia. Salah satu faktor penyebab infeksi di rumah sakit berkaitan dengan kemampuan bakteri MRSA untuk membentuk biofilm. Polysaccharide intercellular adhesin (PIA), yang dikode gen ica, berperan penting dalam akumulasi dan agregasi intraseluler S. aureus. Tujuan penelitian ini adalah menganalisis hubungan antara gen icaA dan icaD terhadap pembentukan biofilm pada MRSA isolat karier dan klinik di RSUD Dr. Soetomo Surabaya. Penelitian ini merupakan penelitian observasional analitik dengan pendekatan cross sectional. Sampel penelitian adalah 47 isolat MRSA diperoleh dari 28 isolat karier dan 19 isolat klinik. Seluruh isolat MRSA mengandung gen mecA. PCR dilakukan untuk mendeteksi gen icaA dan icaD. Pembentukan biofilm diperiksa dengan microtiter plate assay (MTP). Gen icaA terdeteksi pada seluruh isolat sedangkan gen icaD ditemukan pada 96,4\% isolat karier dan seluruh isolat klinik. Hasil MTP positif ditunjukkan pada seluruh isolat karier dan 57,9\% isolat klinik. Hasil statistik menunjukkan perbedaan bermakna pembentukan biofilm antara isolat karier dan klinik MRSA. Proporsi pembentukan biofilm pada bakteri gen icaA/D positif sebesar $82.6 \%$. Tidak didapatkan hubungan antara gen icaA dan icaD dengan pembentukan biofilm.

Kata kunci: Biofilm; gen ica; methicillin-resistant Staphylococcus aureus

Correspondence: K. Kuntaman, Faculty of Medicine, Universitas Airlangga, Jl. Dr. Moestopo 47 Surabaya. E-mail: kuntaman@fk.unair.ac.id

pISSN:2355-8393 • eISSN: 2599-056x • doi: http://dx.doi.org/10.20473/fmi.v54i4.10709

- Fol Med Indones. 2018;54:263-268 • Received 28 Sep $2017 \bullet$ Accepted 22 Mar 2018

- Open access under CC-BY-NC-SA license • Available at https://e-journal.unair.ac.id/FMI/

\section{INTRODUCTION}

Staphylococcus aureus (S. aureus) is a commensal and pathogenic bacterium in humans. This bacteria is a major cause of bacteremia, infective endocarditis, osteoarticular infections, skin and soft tissue infections, pleural pulmonary infections and other medical-related infections (Tong et al 2015). S. aureus may colonize the front part of nasal cavity, armpit folds, groin and gastrointestinal tract. Individuals with $S$. aureus infection are generally infected with bacteria similar to those of colony bacteria (Gordon \& Lowy 2008). 
Methicillin-resistant Staphylococcus aureus (MRSA) is a $S$. aureus whose can not be inhibited by beta-lactam antibiotics. MRSA bacteria have a mecA gene that expresses penicillin-binding protein (PBP)2A as a resistance factor (Gordon \& Lowy 2008). MRSA infection is a worldwide health problem and associated with increased patient morbidity and mortality (Ray et al 2011). Several countries in Asia have increased prevalence of MRSA infections and many hospitals are endemic with MRSA (Chen \& Huang 2014). Kuntaman et al (2016) showed that MRSA's carrier in Dr Soetomo Hospital, Surabaya, reached $8.1 \%$ in 2014 .

One of the factors causing infection in the hospital is related to the ability of bacteria to form biofilm. $S$. aureus bacteria is the most common cause of infection due to biofilm by infecting the patient through contaminated medical devices. Biofilm infections caused by $S$. aureus are usually more severe and difficult to treat. In addition, the biofilm formed can be a reservoir of the spread of infection throughout the body (Otto 2008). Biofilm formation is a pathogenicity factor in both carrier and commensal Staphylococcus bacteria to cause invasive infections (Jain \& Agarwal 2009).

Accumulation and intracellular aggregation are important stages of biofilm formation in $S$. aureus bacteria. This stage involves polysaccharide intercellular adhesin (PIA) whose formation is mediated by enzymes synthesized by genes at ica locus, mainly icaA and icaD gene (Arciola et al 2012). icaA gene produce transmembran protein homolog to $\mathrm{N}$-acetylglucosaminyltransferases and icaD gen product needed to optimize activity of icaA product. PIA forms an exopolysaccharide matrix which is an extracellular polymeric substance (EPS) component of a biofilm (O’Gara 2007). Several studies have demonstrated inconsistency in the detection of ica genes with biofilm formation in MRSA (Eftekhar \& Dadaei 2011, Atshan et al 2012).

The ability of biofilm formation in MRSA of carrier and clinical isolates is a serious problem. MRSA bacteria has resistance to antibiotics, whereas biofilms have structures that cause antimicrobials not working well. This causes infections of biofilm-forming bacteria increasingly difficult to treat (Rezaei et al 2013). Research on the prevalence of biofilm formation in MRSA isolates has been done previously in various places and shows varying results. This study aimed to analyze association between icaA, icaD genes and biofilm formation in MRSA carrier and clinical isolates in Dr. Soetomo Hospital, Surabaya.

\section{MATERIALS AND METHODS}

This was an observational analytic study with cross sectional design. The study was conducted at Clinical Microbiology Laboratory, Dr Soetomo Hospital, Surabaya, and Institute of Tropical Disease, Universitas Airlangga, Surabaya. This study has been approved by the Health Ethics Committee of Dr Soetomo Hospital, Surabaya, No. 342/Panke.KKE/V/ 2017.

The total sample were 47 isolates of MRSA in Dr Soetomo Hospital, Surabaya, consisting of 28 carrier and 19 clinical isolates. Carrier isolates were derived from the collection of MRSA isolates that colonized the nose and throat of the patients in Surgical and Medical Wards, Dr Soetomo Hospital, Surabaya, in 2014 by previous study (Kuntaman et al 2016). MRSA clinical isolates were collection of MRSA from clinical specimens of Dr. Soetomo Hospital patients who came in Laboratory of Clinical Microbiology during the period of March - April 2016, by previous study (Rasita et al 2016). The isolates were identified as MRSA with routine microbiological examination and mecA gene detection by PCR (Kuntaman et al 2016, Rasita et al 2016). The bacterial isolates were stored in medium of TSB with $16 \%$ glycerol and stored at $-80^{\circ} \mathrm{C}$ before the study was conducted.

PCR was performed to detect the presence of icaA and icaD genes. DNA extraction was performed using TE boiling method (Kuntaman et al 2016). The bacterial colonies were suspended on an ependorf tube containing $100 \mu \mathrm{l}$ TE buffers. The suspension was heated with thermostat (Eppendorf, North America) in a temperature of 95 OC for 10 minutes. The tubes were then cooled and centrifuged at $10,000 \mathrm{rpm}$ for 10 minutes. The DNA extracts was aspirate from supernatant and stored at $20^{\circ} \mathrm{C}$ until used. The mixture for PCR reactions was 25 $\mu \mathrm{L}$ consisting of $12.5 \mu \mathrm{L}$ PCR Mix (GoTaq ${ }^{\circledR}$ Green Master Mix, Promega, Madison, USA), $1 \mu \mathrm{L}$ each primer, $5 \mu \mathrm{L}$ bacterial DNA template, and added with distilled water to obtain the expected total volume. icaA primer used was icaA-F primer: 5'-ACACTTGCTGGC GCAGTCAA-3 'and icaA-R: 5'-TCTGGAACCAACA $\mathrm{T}-3$, which produces amplicons of $188 \mathrm{bp}$ (Rohde et al 2001). The icaD primer used was primer icaD-F: 5'ATGGTCAAGCCCAGACAGAG-3 'and icaD-R: 5'CGTGTTTTCAACATTTAATGCAA-3', which produced amplicons of 198 bp (Rohde et al 2001). DNA amplification performed by using a PCR thermal cycler (Icycler, Biorad Thermal Cycler). The PCR conditions used for icaA amplification were initial denaturation of $94^{\circ} \mathrm{C}$ for 5 minutes followed with 30 cycles of $94^{\circ} \mathrm{C}$ for 1 minute denaturation, $55^{\circ} \mathrm{C}$ for 1 minute annealing, $72^{\circ} \mathrm{C}$ for 1 minute extension and followed by a final extension of $72^{\circ} \mathrm{C}$ for 10 minutes. The PCR conditions 
used for icaD amplification were initial denaturation of $94^{\circ} \mathrm{C}$ for 5 minutes, followed by 30 cycles of $94^{\circ} \mathrm{C}$ for 30 seconds denaturation, $55^{\circ} \mathrm{C}$ for 30 seconds annealing, $72^{\circ} \mathrm{C}$ for 1 minute (extension) and followed by a final extension of $72^{\circ} \mathrm{C}$ for 10 minutes (Mirzaee et al 2014). Production of PCR results was visualized in a $1.5 \%$ agarose gel and used a $100 \mathrm{bp}$ DNA ladder marker (Genaid, Taiwan). PCR fragments were visualized with electrophoresis (Mupid®-2plus Submarine-type electrophoresis system, Takara, Inc., Japan) and Ethidium Bromide staining (Nacalai Tesque Inc., Kyoto, Japan). DNA bands were observed using a UV trans-illuminator (Spectroline, Spectronic, USA) and being documented (Digibox, Seoul, Korea). The icaA and icaD genes were categorized as one variable because theoretically both genes work together to function optimally. Genes with positive icaA and icaD genes were categorized as positive icaA/D and if one of the genes was negative it was categorized as icaA/D negative.

Biofilm formation was detected by microtiter plate assay method with adjustment (Stepanovic et al 2007; Kawamura et al 2011; Mirzaee et al 2014). Briefly, the wells of flat-bottomed 96-well polystyrene micro-titer plate (Nunclon Delta Surface, Thermo Fischer Scientific, China) were filled with $180 \mu \mathrm{l}$ of trypticase soy broth (TSB) (Oxoid, Basingstoke, UK) supplemented with $1 \%$ glucose (Merck, Darmstadt, Germany). Furthermore, $20 \mu \mathrm{l}$ of bacterial suspension equivalent with 0.5 standard MacFarland turbidity was added to the wells. Incubation was carried out for 24 hours at $37^{\circ} \mathrm{C}$, then the wells were decanted. The well was washed three times with $300 \mu \mathrm{l}$ phosphate buffered saline (Oxoid, Basingstoke, UK) pH 7.2 then fixed with $150 \mu \mathrm{l}$ methanol (Merck, Darmstadt, Germany) for 20 minutes. Micro-titers plate were emptied and left to air dry overnight in an inverted position at room temperature. Staining was done by adding $150 \mu \mathrm{L} 0.1 \%$ crystal violet (Merck, Darmstadt, Germany) then the plate was washed and left to dry. The embedded crystal violet were diluted with $150 \mu \mathrm{L}$ of ethanol (Merck, Darmstadt, Germany) $95 \%$ per well then the optical density (OD) was measured using a micro-plate reader (iMark microplate reader, Biorad) with a wavelength of 595 $\mathrm{nm}$. Each assay was performed in a triplicate. Wells were filled with $200 \mu \mathrm{l}$ TSB supplemented with $1 \%$ glucose medium used as negative control. OD samples were calculated to obtain mean OD. OD of negative control was used to calculate optical density cut-off (ODc). ODc value was determined as mean negative control OD $+3 x$ standard deviation from negative control. OD samples were then categorized as strong biofilm producer $(\mathrm{OD}>4 \mathrm{xODc})$, intermediate biofilm producer $(2 \mathrm{xODc}<\mathrm{OD}<4 \mathrm{xODc})$, weak biofilm producer (ODc $<\mathrm{OD}<2 \mathrm{xODc}$ ) and no biofilm producer (OD<ODc). This study re-categorized strong, moderate and weak biofilm producers into categories of positive biofilm formation. No biofilm producer was included in the category of negative biofilm formation.

The result was analysed using comparative statistics. Statistical analysis was performed using SPSS version 16. $\mathrm{P}<0.05$ was regarded as significant. Variable of this study was icaA/D gene, biofilm formation, carrier and clinical MRSA isolates.

\section{RESULTS}

The icaA gene was detected in all (100\%) carrier isolates and clinical isolates. The icaD gene was detected in $27(96.4 \%)$ of carrier isolates and all (100\%) clinical isolates. Based on re-categorization, there were $97.9 \% \mathrm{icaA} / \mathrm{D}$ positive samples and $2.1 \% \mathrm{icaA} / \mathrm{D}$ negative sample. Fisher exact analysis showed no significant differences in icaA/D gene detection between carrier and clinical isolates.

Carrier isolates belonging to strong biofilm producer were $4(14.3 \%)$ isolates, moderate biofilm producer 10 $(35.7 \%)$ isolates, and weak biofilm producer $14(50.0 \%)$ isolates. Clinical isolates belonging to strong biofilm producer were as many as $1(5.3 \%)$ isolates, moderate biofilm producer $2(10.5 \%)$ isolates, weak biofilm producer $8(42.1 \%)$ isolates, and no biofilm producer 8 $(42.1 \%)$ isolates. Based on re-categorization, all $(100 \%)$ carrier isolates and $57.9 \%$ of clinical isolates were biofilm producer. Fisher exact analysis showed significant differences in biofilm formation between carrier and clinical isolates.

Comparison between presence of icaA/D genes and biofilm formation was analysed. The number of biofilm formation is the total biofilm formation in carrier and clinical isolates, comprising 39 positive samples and 8 biofilm-forming negative samples. The proportion of positive biofilm formation in isolate with positive icaA/D genes was $82.6 \%$. Fisher exact analysis results showed no significant differences between presence of icaA/D genes MRSA with biofilm formation $(p=0.83)$. 
Table 1. Comparison of icaA/D genes detection in MRSA isolates

\begin{tabular}{lccccccc}
\hline \multirow{2}{*}{ ica A/D gene } & \multicolumn{2}{c}{ Carrier isolate } & \multicolumn{2}{c}{ Clinical isolate } & \multicolumn{2}{c}{ Total } & \multirow{2}{*}{$\mathrm{p}$} \\
\cline { 2 - 7 } & $\mathrm{n}$ & $\%$ & $\mathrm{n}$ & $\%$ & $\mathrm{n}$ & $\%$ & \\
\hline Positive & 27 & 96.4 & 19 & 100,0 & 46 & 97.9 & \\
Negative & 1 & 3.6 & 0 & 0.0 & 1 & 2.1 & \multirow{2}{*}{0.596} \\
\hline Total & 28 & 100.0 & 19 & 100.0 & 47 & 100.0 & \\
\hline
\end{tabular}

Table 2. Comparison of biofilm formation in MRSA isolates

\begin{tabular}{lccccccc}
\hline \multirow{2}{*}{ Biofilm Formation } & \multicolumn{2}{c}{ Carrier isolate } & \multicolumn{2}{c}{ Clinical isolate } & \multicolumn{2}{c}{ Total } & \multirow{2}{*}{$\mathrm{p}$} \\
\cline { 2 - 7 } & $\mathrm{n}$ & $\%$ & $\mathrm{n}$ & $\%$ & $\mathrm{n}$ & $\%$ & \\
\hline Positive & 28 & 100.0 & 11 & 57.9 & 39 & 83.0 & \\
Negative & 0 & 0.0 & 8 & 42.1 & 8 & 17.0 & \multirow{2}{*}{0.001} \\
\hline Total & 28 & 100.0 & 19 & 100.0 & 47 & 100.0 & \\
\hline
\end{tabular}

\section{DISCUSSION}

The ica-dependent pathway is the most well understood mechanism in the formation of biofilms in S. aureus and involves ica gene. The icaA and icaD genes play a role in the regulation and formation of PIA. PIA facilitates intracellular accumulation and aggregation stages to further form the exopolysaccharides as a biofilm EPS component (O'Gara 2007). High detection of the icaA and icaD genes was also found in other studies. Atshan et al (2012) study in the MRSA clinical isolates showed $100 \%$ detection of icaA and icaD genes. A study on burn patient isolates in Iran found that all MRSA isolates had icaA and icaD genes (Moghadam et al 2014). Detection of icaA and icaD genes in S. aureus carrier isolates from hospital staff was $22.2 \%$ (Satorres \& Alcaraz 2007).

Primer selection factor for PCR is believed to cause differentiation of icaA and icaD gene detection results in $S$. aureus. Several studies used icaA and icaD primers from S. epidermidis genetic sequences RP62A where icaA and icaD base sequences showed only $76 \%$ and $72 \%$ similarity with $S$. aureus ATCC 35556 . This would have different results if $\mathrm{S}$. epidermidis icaA and icaD primers were used in $S$. aureus (Rohde et al 2001). This study used a suitable primer for $S$. aureus genetic sequencing.

Sampling site is also likely to influence the detection of ica gene. Satorres and Alcaraz (2007) study assumes that ica gene is more prevalent in Staphylococcus bacteria isolated from patients and hospital personnel than from healthy individuals and non-hospital communities. High detection of ica gene in this study was probably because all carrier and clinical isolates were obtained from patients at Dr. Soetomo Hospital.

The results of biofilm formation in carrier isolates were similar to those in Iran showing that all MRSA carrier isolates were able to form biofilms (Rezaei et al 2013). The results of clinical isolates study were similar to those of MRSA in Tehran where biofilm-producing bacteria were $57.8 \%$ and all of them were weak biofilm producers (Eftekhar \& Dadaei 2011). The results of statistical analysis showed significant differences of biofilm formation between carrier and clinical isolates. The ability of biofilm production in carrier isolates was higher than that of clinical isolates. This indicates that carrier isolates have a higher ability to adhere to the environment to perform colonization on the surface of the body. The MRSA carrier is thought to be a persister cell suspected of having higher biofilm production capabilities. MRSA bacteria is a bacteria that is naturally pathogenic and virulent so that it may directly cause infection in humans. This is in contrast to opportunistic bacteria, such as Staphylococcus epidermidis, which requires certain circumstances such as individual immuno-compromised conditions or biofilm formation in the device to cause infection (Otto 2008).

The statistical test results showed no association between icaA/D genes with biofilm formation in MRSA. This suggests that biofilm formation in MRSA is not only determined by the presence of genes encoding biofilms, in this case the icaA/D genes, but also by other factors. The expression of ica gene can be influenced by environmental factors such as media composition, ethanol, salt content, iron content, and anaerobic environment (Arciola et al 2012). The expression of the ica gene is also regulated by various genes such as sigma B (sigB), staphylococcal accessory regulator A (SarA), and accessory gene regulator (agr). These genes interact through complex signaling mechanisms for biofilm formation (Serray et al 2016).

The inability of biofilm formation in bacteria with ica genes may be attributed to various factors, such as point mutations in ica gene (Cramton et al 1999) or ica gene 
translation regulation problem due to the presence or absence of ica mRNA (Liberto et al 2009). Defect in early attachment stage also causes bacteria with the ica gene to be unable to form biofilms (Hall-Stoodley et al 2004). Biofilm formation also occurs in bacteria with negative ica genes which is described by alternative mechanisms of biofilm formation in $S$. aureus. The formation of ica-independent biofilms involves protein adhesins such as accumulated associate proteins (Aap), biofilm associated proteins (Bap) and fibronectinbinding proteins $(\mathrm{FnBP})$ that facilitate intercellular aggregation and form biofilm matrix components (Arciola et al 2012). Study by O’Neill et al. (2007) suggest that biofilm formation in MRSA occurs icaindependently and involves protein adhesin. Atshan et al. (2012) argue that differences in genotypic and phenotypic characteristics are due to complex genetic heterogeneity in biofilm formation, not only due to the presence or absence of biofilm forming genes.

\section{CONCLUSION}

There were no significant differences in icaA/D genes in carrier and clinical MRSA isolates. The ability of biofilm formation in carrier isolate is significantly different than that of clinical isolate. There was no association between presence of icaA/D genes with biofilm formation in MRSA.

\section{REFERENCES}

Arciola CR, Campoccia D, Speziale P, et al (2012). Biofilm formation in Staphylococcus implant infections. A review of molecular mechanisms and implications for biofilm-resistant materials. Biomaterials 33, 5967-5982

Atshan SS, Nor Shamsudin M, Sekawi Z, et al (2012). Prevalence of adhesion and regulation of biofilmrelated genes in different clones of Staphylococcus aureus. J. Biomed. Biotechnol, 1-10

Chen CJ, Huang YC (2014). New epidemiology of Staphylococcus aureus infection in Asia. Clin. Microbiol. Infect 20, 605-623

Cramton SE, Gerke C, Schnell NF, et al (1999). The intercellular adhesion (ica) locus is present in Staphylococcus aureus and is required for biofilm formation. Infect. Immun. 67, 5427-5433

Eftekhar F, Dadaei T (2011). Biofilm formation and detection of icaAB genes in clinical isolates of methicillin resistant Staphylococcus aureus. Iran. J. Basic Med. Sci 14, 132-136

Gordon RJ, Lowy FD (2008). Pathogenesis of Methicillin-Resistant Staphylococcus aureus Infection. Clin. Infect. Dis 46, S350-S359
Hall-Stoodley L, Costerton JW, Stoodley P (2004). Bacterial biofilms: from the Natural environment to infectious diseases. Nat. Rev. Microbiol 2, 95-108

Jain A, Agarwal A (2009). Biofilm production, a marker of pathogenic potential of colonizing and commensal staphylococci. J. Microbiol. Methods 76, 88-92

Kawamura H, Nishi J, Imuta N, et al (2011). Quantitative analysis of biofilm formation of methicillin-resistant Staphylococcus aureus (MRSA) strains from patients with orthopaedic device-related infections. FEMS Immunol. Med. Microbiol 63, 10-15

Kuntaman K, Hadi U, Setiawan F, et al (2016). Prevalence of methicillin resistant Staphylococcus aureus from nose and throat of patients on admission to Medical Wards of Dr Soetomo Hospital, Surabaya, Indonesia. Southeast Asian J. Trop. Med. Public Health 47, 66-70

Liberto MC, Matera G, Quirino A, et al (2009). Phenotypic and genotypic evaluation of slime production by conventional and molecular microbiological techniques. Microbiol. Res 164, 522528

Mirzaee M, Peerayeh SN, Behmanesh M, et al (2014). Detection of intracellular adhesion (ica) gene and biofilm formation Staphylococcus aureus isolates from clinical blood cultures. J. Med. Bacteriol 3, 1-7

Mirzaee M, Peerayeh SN, Ghasemian A (2014). Detection of icaABCD genes and biofilm formation in clinical isolates of methicillin resistant Staphylococcus aureus. Iran. J. Pathol. 9(4), 257-262

Moghadam SO, Pourmand MR, Aminharati F (2014). Biofilm formation and antimicrobial resistance in methicillin-resistant Staphylococcus aureus isolated from burn patients, Iran. J. Infect. Dev. Ctries. 8(12), 1511-1517

O'Gara JP (2007). ica and beyond: Biofilm mechanisms and regulation in Staphylococcus epidermidis and Staphylococcus aureus. FEMS Microbiol. Lett 270, 179-188

O’Neill E, Pozzi C, Houston P, et al (2007). Association between methicillin susceptibility and biofilm regulation in Staphylococcus aureus isolates from device-related infections. J. Clin. Microbiol 45, 13791388

Otto M (2008). Staphylococcal biofilms. Curr. Top. Microbiol. Immunol. 322, 207-228

Rasita YD, Debora K, Kuntaman K (2016). Perbandingan gen pvl pada methicillin susceptible Staphylococcus aureus dan methicillin resistant Staphylococcus aureus dari isolat klinis di RSUD Dr. Soetomo, Surabaya. An unplublished thesis. Surabaya, Universitas Airlangga

Ray P, Gautam V, Singh R (2011). Methicillin-resistant Staphylococcus aureus (MRSA) in developing and developed countries?: implications and solutions. Reg. Heal. Forum 15, 74-82 
Rezaei M, Moniri R, Mousavi SGA, et al (2013). Prevalence of biofilm formation among methicillin resistance Staphylococcus aureus isolated from nasal carriers. Jundishapur J. Microbiol 6, 0-4

Rohde H, Knobloch JK, Horstkotte MA, et al (2001). Correlation of Staphylococcus aureus icaADBC genotype and biofilm expression phenotype. J. Clin. Microbiol 39, 4595-6

Satorres SE, Alcaraz LE (2007). Prevalence of icaA and icaD genes in Staphylococcus aureus and Staphylococcus epidermidis strains isolated from patients and hospital staff. Cent. Eur. J. Public Heal $15,87-90$
Serray B, Oufrid S, Hannaoui I, et al (2016). Genes encoding adhesion factors and biofilm formation in methicillin resistant Staphylococcus aureus in Morocco. J. Infect. Dev. Ctries 10, 863-869

Stepanovic S, Vukovic D, Hola V, et al (2007). Quantification of biofilm in microtiter plates: Overview of testing conditions and practical recommendations for assessment of biofilm production by staphylococci. Apmis 115, 891-899

Tong SYC, Davis JS, Eichenberger E, et al (2015). Staphylococcus aureus infections: Epidemiology, pathophysiology, clinical manifestations, and management. Clin. Microbiol. Rev 28, 603-661 